THE BASE OF THE PYRAMID PROMISE 



\title{
THE BASE OF THE
}

\section{PYRAMID PROMISE}

\author{
Building Businesses with Impact \\ and Scale
}

TED LONDON

S TA NFORD BUSINES B OOKS

An Imprint of Stanford University Press

Stanford, California 
Stanford University Press

Stanford, California

(C) 2016 by the Board of Trustees of the Leland Stanford Junior University. All rights reserved.

No part of this book may be reproduced or transmitted in any form or by any means, electronic or mechanical, including photocopying and recording, or in any information storage or retrieval system without the prior written permission of Stanford University Press.

Special discounts for bulk quantities of Stanford Business Books are available to corporations, professional associations, and other organizations. For details and discount information, contact the special sales department of Stanford University Press. Tel: (650) 736-1782, Fax: (650) 736-1784

Printed in the United States of America on acid-free, archival-quality paper

Library of Congress Cataloging-in-Publication Data

Names: London, Ted, 1963- author.

Title: The base of the pyramid promise : building businesses with impact and scale / Ted London.

Description: Stanford, California : Stanford Business Books, an imprint of Stanford University Press, 2016. | Includes bibliographical references and index.

Identifiers: LCCN 2015014934 | ISBN 9780804791489 (cloth : alk. paper)

Subjects: LCSH: Social entrepreneurship-Developing countries. | Industrial management-Developing countries. Success in business-Developing countries. | Business planning_Developing countries. | Markets-Developing countries. | Poverty-Developing countries. | Low-income consumersDeveloping countries.

Classification: LCC HD60.5.D44 L66 2016 | DDC 658.4/08091724-dc23

LC record available at http://lccn.loc.gov/2015014934

ISBN 978-0-8047-9733-7 (electronic) 
To Meghan, Zach, and Ariana; thanks for all the joy you bring to my life. 
